\title{
Lipoprotein(a) and its Clinical Importance
}

\author{
Malihe Moammeri Salahshooh \\ (MSc) \\ Department of Biochemistry, Faculty \\ of Medicine, Mashhad University of \\ Medical Sciences, Mashhad, Iran \\ Farnaz Zahedi Avval (MD, PhD) \\ Department of Biochemistry, Faculty \\ of Medicine, Mashhad University of \\ Medical Sciences, Mashhad, Iran \\ Fatemeh Sadabadi (PhD) \\ Department of Modern Sciences and \\ Technologies, Faculty of Medicine, \\ Mashhad University of Medical \\ Sciences, Mashhad, Iran \\ Corresponding author: Malihe \\ Moammeri Salahshooh \\ Email: Malihe.salahshur@gmail.com \\ Tel: +989155584570 \\ Address: Mashhad University of \\ Medical Sciences. Mashhad. Iran \\ Received: 29 Dec 2018 \\ Revised: 17 Jun 2019 \\ Accepted: 16 Jul 2019 \\ c) (i) (8)
}

This work is licensed under a Creative Commons Attribution 4.0 License.

\begin{abstract}
Reports have shown that lipoprotein (Lp)(a) can serve as an indicator of atherosclerosis and cardiovascular diseases. Several cardiovascular disease risk factors including age, ethnicity and type 2 diabetes mellitus have been linked to Lp(a) metabolism. Given the structural similarity between $\mathrm{Ip}(\mathrm{a})$ and plasminogen, there may be a relationship between $\mathrm{Lp}(\mathrm{a})$ level and thrombosis and atherogenesis.

In this review, we summarize the latest data about Lp(a) and related conditions on the Publled database using the following keywords: "Lp(a) and diseases" and "Lp(a) and racial groups". All available information was extracted and categorized according to the purpose of this study. In conclusion, evidence suggest that increased level of $\mathrm{Lp}(\mathrm{a})$ results in coronary artery disease and increases the risk of ischemic stroke. Lack of Lp(a) has no adverse effect on human health. Moreover, Lp(a) can be effective in wound healing as it degrades apolipoprotein(a) products which might have anti-tumor and anti-angiogenetic effects.
\end{abstract}

Keywords: Lipoprotein(a), Atherosclerosis, Apo(a).

This paper should be cited as: Moammeri Salahshooh M, Sadabadi F [ Lipoprotein(a) and its Clinical Importance ]. mljgoums. 2020; 14(2): 1-8 


\section{INTRODUCTION}

Lipoprotein (LP) (a) is a unique lipoprotein and an independent risk factor for vascular diseases. High level of this lipoprotein $(300 \mathrm{mg} / \mathrm{dl})$ in humans, especially when accompanied with other lipids or thrombogenic factors, increases the risk of developing cardiovascular diseases (CVDs).

Studies have shown that the level of $L p(a)$ is highly variable according to individual genetic control. The $\mathrm{Lp}$ (a) level varies widely and is controlled by genetic factors. Some reports have shown that $\operatorname{Lp}(\mathrm{a})$ is highly associated with arterial wall and atherosclerosis, displaying many thrombogenic properties, but no certain function has yet been identified for $\operatorname{Lp}(\mathrm{a})(1)$.

Different studies have highlighted the relationship between $\mathrm{Lp}(\mathrm{a})$ and risk of developing CVDs. Direct deposition of Lp(a) in arterial wall increases low-density lipoprotein (LDL) oxidation. Despite the pathogenic effects of $L p(a)$, it is not yet proven that decreased concentration of $\operatorname{Lp}(\mathrm{a})$ can reduce the risk of CVD.

The discovery of the structural similarity between apo (a) and plasminogen shed light on the possible association between plasma Lp concentration and thrombosis/athrogenosis. It is hypothesized that $\mathrm{Lp}$ (a) intervenes with the fibrinolytic system by competing with plasminogen at its endothelial cell bindings site. This leads to fibrinolysis inhibition and intra-arterial thrombus formation and consolidation. In this hypothesis, $\mathrm{Lp}(\mathrm{a})$ is a factor linking athrogenosis to thrombogenosis (Figure 1) (2).

\section{Lipoprotein (a) Biology and Importance}

As shown in figure 2, chemical structure of $\mathrm{Lp}(\mathrm{a})$ is similar to that of LDL. In the $\mathrm{Lp}(\mathrm{a})$ structure, apo(a) is connected to apoB (100) through disulfide bonds. Lipoprotein (a) is synthesized in the liver and its concentration in plasma ranges from less than $1 \mathrm{mg} / \mathrm{dl}$ to over $1000 \mathrm{mg} / \mathrm{dl}$. However, $\mathrm{Lp}$ (a) level of 20 to 30 $\mathrm{mg} / \mathrm{dl}$ doubles the risk of CVDs.

Black people seem to have distinctively higher levels of $L p(a)$ compared to Caucasians and Asians; but this difference is not associated with increased incidence of CVD. Nevertheless, the risk of this factor in progression of CVD in black people should be taken into account. Sex and age also have little effect on Lp(a) level (2).

\section{Lipoprotein (a) Structure}

Lipoprotein (a) particles were first detected by Berg in 1963 (3). This particle has a round macromolecular complex with a thickness of about $25 \mathrm{~nm}$ and density of 1.05-1.12 g/ml. Another protein called apo(a) is produced through non-covalent disulfide bonds with 550 $\mathrm{kDa}$ apoB100 (4). The protein consists of an inactive domain of protease or serine protease with 94\% similarity of amino acid sequence with that of plasminogen. In addition, two other domains exist in heavy chain threedimensional structure that contains large amounts of glycosyl called "Kringle"(5).

Apolipoprotein(a) serine protease domain shows a substitution of serine for arginine in activation site that is equivalent to plasminogen. Similar to plasminogen III, this entity prevents the tissue plasminogen activators (t-pA) such as urokinase or streptokinase from converting $\operatorname{Lp}(\mathrm{a})$ to active protease (6). One domain of Kringle apo(a) is similar to Kringle V plasminogen and only 9\% difference in amino acid is observed. The rest of Kringle IV within the structure of plasminogen correlates with 10 different structure in apo(a).

Only Kringle type 2 is permanently present in the structure of apo(a) which has $84 \%$ similarity to that of plasminogen; thus KringleV exists as a unique copy, while KringleIV is 10-40times repeated in the structure of apo(a). KringleIV repetition times are genetically determined. Repetition times range from 12 to 51 times, producing 34 different apo(a) isoforms $(5,6)$.

Six different forms for $\operatorname{Lp}(\mathrm{a})$ have been identified using electrophoresis and immunoblotting: Lp(a) F, Lp(a) BT, Lp(a) S1, Lp(a) S2, Lp(a) S3 and Lp(a) S4. The letters F (fast), S (slow), B (similar apoB100) are related to apo(a) movement compared to apoB100. Isoforms of apo(a) are indicative of $\mathrm{Lp}$ (a) concentration in plasma. Smaller proteins are secreted more effectively compared to proteins with higher molecular weights.

The concentration of $\mathrm{Lp}(\mathrm{a})$ is mostly dependent on isoforms with smaller KIV, which also have more thrombogenic activity. Therefore, there is an inverse relationship between molecular weight and apo(a) isoforms and $\mathrm{Lp}$ (a) plasma concentration. The presence 
of seventh allele called $\mathrm{Lp}(\mathrm{a})$ (o) null that leads to lipoproteins deficiency in plasma, has been shown using sensitive techniques. However, its serum levels have not yet been determined (6).

The presence of apoB100 in $\mathrm{Lp}(\mathrm{a})$ causes precipitation of lipoprotein with LDL. In the chemical deposition method, LDL is calculated using the Friedewald formula. Therefore, in patients with high $\mathrm{Lp}(\mathrm{a})$ concentration, $L p(a)$ level should be adjusted in the formula to correctly calculate the LDL concentration (7).

\section{Lipoprotein (a) Measurement}

Generally, the concentration of $\mathrm{Lp}(\mathrm{a})$ is determined by antibody-based methods such as radioimmunoassay, radial immunodiffusion (8), ELISA and nephelometry or turbidometry using monoclonal antibody against apo(a). Notable alterations in apo(a) molecular weight cause volume to molar ratio variability among people. Different studies must be compared to standardize the methodologies used to determine $\mathrm{Lp}(\mathrm{a})$. Thus, methodologies need to be improved to determine $\mathrm{Lp}$ (a) level (9).

\section{Lipoprotein (a) Synthesis and Metabolism}

Despite the structural similarities between LDL and $\mathrm{Lp}(\mathrm{a})$, little is known about $\mathrm{Lp}(\mathrm{a})$ synthesis and metabolism except for the fact that it is entirely independent of LDL. Studies have shown that the apo(a) synthesis occurs in the liver and its relationship with apoB100 is built in epithelial cells (10). There is no proportionality between apo(a) and apoB100 synthesis pathways, nor between $\operatorname{Lp}(\mathrm{a})$ and plasminogen. In patients with high triglyceride levels, $L p(a)$ is reduced which may be due to the increased clearance of lipoprotein $(11,12)$. Interestingly, the concentration of $\operatorname{Lp}(\mathrm{a})$ is not related to serum lipoprotein lipase activity. In this line, it has been shown that stimulation of lipolysis during heparin therapy does not affect serum Lp(a) concentrations (13).
Several studies have shown that $\mathrm{Lp}(\mathrm{a})$ binds to specific LDL receptors in spite of less affinity (14). There are two interpretations for different tendencies: 1) A portion of $\mathrm{Lp}(\mathrm{a})$ domains bind to apo(a) close to the LDL receptor domain, 2) apo(a) does not bind to apoB100 in its receptor binding sites(14). Evidence suggest that LDL receptor is not very important in plasma Lp(a) uptake by cells.

Large clinical studies have reported that statins have no effect on $L p(a)$ concentration. Statins stimulate expression of LDL receptors, resulting in increased $L p(a)$ plasma uptake; hence it is expected that $\mathrm{Lp}(\mathrm{a})$ level decreases. Macrophages play an important role in $L p(a)$ uptake. By further uptake of lipoproteins, macrophages transform to foam cell that is a major mechanism of atherogenesis (15). Although the LDL receptor plays a role in $\mathrm{Lp}$ (a) uptake, its effectiveness in the process is limited (16).

\section{Apolipoprotein (a) Genetics and Related Ethnic Aspects}

The gene encoding apo(a) protein in humans has been cloned and sequenced in 1987. The gene is located on human chromosome 6q2627 , in the same cluster of plasminogen. There is $70 \%$ similarity between this gene and plasminogen gene.

Since genetic variability of apo(a)and other genes are dependent on $L p(a)$ synthesis and metabolism, the plasma lipoprotein levels may vary over 1,000 times among different individuals (17). Apolipoprotein (a) gene is responsible for $91 \%$ of variability in $\mathrm{Lp}(\mathrm{a})$ concentrations. Greater allele frequency variations among different races indicates that the racial factors have a significant impact on the level of $\operatorname{Lp}(\mathrm{a})$ (18).

In a study performed on 7 races, Lp(a) polymorphism ranged from $17 \%$ to $77 \%$ correlation with variations in $\mathrm{Lp}(\mathrm{a})$ concentrations (19).

Figure 1- Competitive inhibition of plasminogen and $\operatorname{Lp}(a)$

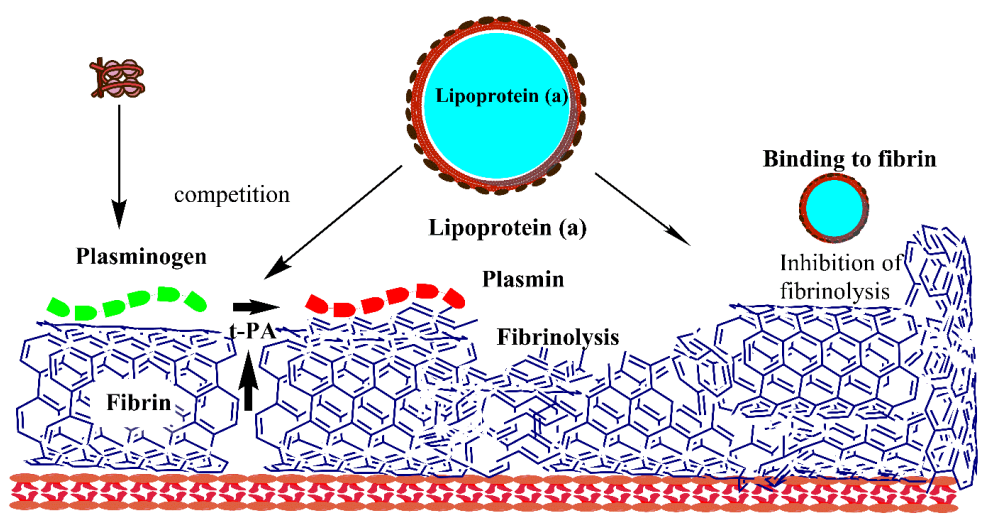




\section{Lipoprotein (a) and Racial Groups}

Lipoprotein (a) concentration varies widely in the general population. Generally, Lp(a) concentration is lower in bigger isoforms and higher in CVD patients. In the AfricanAmerican population, normal distribution shifts toward higher concentrations of $\mathrm{Lp}$ (a) (20). High level of $L p(a)$ is a risk factor for CVD and stroke (21).

\section{Lipoprotein (a) Pathogenicity}

Similar to acute-phase proteins (haptoglobin, alpha-1 antitrypsin and C-reactive protein), $\mathrm{Lp}$ (a) increases temporarily in inflammation as a result of tissue damage but will return to baseline values within a month (22). Following a heart attack, the level of $\mathrm{Lp}(\mathrm{a})$ increases in the first 24 hours and may return to baseline level within 30 days (23). In addition, $\mathrm{Lp}(\mathrm{a})$ increases in chronic inflammatory diseases, such as rheumatoid arthritis (24), systemic lupus erythematosus (25), acquired immunodeficiency syndrome (26), and some other conditions including heart transplantation (27), chronic renal diseases (28) as well as pulmonary arterial hypertension (29).

$\mathrm{Lp}$ (a) decreases in some liver diseases or by intake of steroid hormones (28). The relationship between $\mathrm{Lp}(\mathrm{a})$ and diabetes mellitus has not been firmly established yet. Some studies demonstrated a link between diabetes mellitus and increased levels of $\mathrm{Lp}$ (a) (30).

Contrary to other studies, no difference was found in the concentration of $\mathrm{Lp}(\mathrm{a})$ in the San Antonio Heart Study (31).

Direct deposition of $\mathrm{Lp}$ on arterial walls, similar to LDL oxidation, may be involved in the process of atherogenesis. In fact, $L p(a)$ is more tolerant to oxidation than LDL, which may be a result of facilitated uptake by macrophages (15). The effect of $\operatorname{Lp}(\mathrm{a})$ on the arteries is still open to debate. The relationship between inflammatory cytokines such as $\alpha$ TNF-, TGF- $\beta$, IL-6, MCP-1 and Lp(a) has been reported $(32,33)$. In addition, reduced fibrinolysis, as well as platelet aggregation is the result of adhesion molecules expression, infiltration and migration of endothelial cells and smooth muscle cells and foam cells formation.

\section{Lipoprotein (a) as a Risk Factor for Atherosclerosis}

There are numerous research indicating an association between Lp(a) and CVD. Kostner et al. reported that the risk of CVD increases up to 2.3 times in patients with more than 50 $\mathrm{mg} / \mathrm{dl}$ of Lp(a) (34). However, Porter and Riches estimated that the risk of CVD doubles with $\mathrm{Lp}$ (a) levels above $20 \mathrm{mg} / \mathrm{dl}$ (32). The relationship between $\mathrm{Lp}(\mathrm{a}), \mathrm{CVD}$ and ischemic events has also been shown by Murai et al. (35). In a Japanese population, a study reported that the risk of CVD in individuals with high $\mathrm{Lp}$ (a) concentration decreases with age (36).

In a Brazilian population, the risk of developing coronary artery disease increases by 2.3 when the level of $\operatorname{Lp}(\mathrm{a})$ reached above $25 \mathrm{mg} / \mathrm{dl}(37)$.

Although most studies have not reported a relationship between gender and $L p(a)$ levels, it seems that increased level of $\mathrm{Lp}$ is a more specific risk factor in women than in men (38). In a study conducted on a Atherosclerosis Risk in Communities (ARIC) population, Lp(a) was considered a risk factor for sex-related atherosclerosis because plasma $\mathrm{Lp}(\mathrm{a})$ concentration was higher in women than in men (39). In postmenopausal women, increased level of $\mathrm{Lp}(\mathrm{a})$ and triglycerides are considered as predictors of coronary artery disease (40). Early prospective studies have shown no relationship between $\mathrm{Lp}$ (a) and risk of myocardial infarction $(41,42)$. In a study performed on 68 patients with CVD, smallsized apo(a) was identified as an independent risk factor (43). Apolipoprotein(a) is accompanied with plasminogen or fibronectin, which can be either bound or separated(44). Studies have shown that $\mathrm{Lp}$ (a) can bind to glycosaminoglycans (45), fibrin (46), platelets (47), Beta-2 glycoprotein (48) and glycoprotein 330 (gp330)/megalin (49) in human plasma. Lp (a) increases during fibrinolysisin patients with stroke (50).

\section{Lipoprotein (a) and Cancer}

The relationship of $\mathrm{Lp}(\mathrm{a})$ with certain cancers is well documented. Increase in $L p(a)$ levels has been reported in breast cancer (51) and lung cancer (52); however, Lp(a) level decreases in liver cancer (53) since the main site of apo(a) synthesis is impaired in this condition. Controlling angiogenesis should be considered as a main therapeutic objective. Early studies showed that removal of primary tumors increases the risk of cancer progression and metastasis. The led to the notion that primary tumors might produce angiostatic factors that inhibit tumor growth and 
metastasis (54).

Expressing cDNA fragment containing apo (a), KIV-9, KIV-10 and KV in murine CT26 colon carcinoma line inhibited liver metastasis in BALB/c mice (54). Effect of angiogenic activity on endothelial deformation is as follows (55): $\quad \mathrm{KV}>\mathrm{KI}>\mathrm{KIII}>\mathrm{KII}>\mathrm{KIV}$. Angiogenesis is required for wound healing and endothelium regeneration (56). Yano et al. reported that $\mathrm{Lp}(\mathrm{a})$ accumulation contributes to wound healing and stimulates migration and proliferation of vascular endothelial cells (57). In summary, Kringles are produced by break down of apo(a) and exhibit anti-tumor and anti-angiogenesis properties, while $\mathrm{Lp}(\mathrm{a})$ facilitates wound healing by activating endothelial repair of injured endothelium and removing angiogenesis .

Several studies have shown that $L p(a)$ reduction is associated with progression of hepatocellular carcinoma (58).

\section{Drugs and $L p(a)$}

Taking statins have different effects on plasma $\mathrm{Lp}$ (a) levels.
Nicotinic acid and its derivatives can reduce $\mathrm{Lp}$ (a) levels by up to $30 \%$. The most effective method for lowering $\mathrm{Lp}(\mathrm{a})$ is extracorporeal elimination with apheresis (59). Taking statins or fibrates medication, the traditional treatment for hypertriglyceridemia, do not steadily cause $\mathrm{Lp}$ (a) reduction. Ezetimibe lowers Lp(a) concentration as much as $29 \%$. Other agents that could lower $\mathrm{Lp}$ (a) concentration include mixture of L-lysine and ascorbate, thyromimetics, L-carnitine, cholesterylester transfer protein inhibitors, as well as monoclonal antibodies such as anti-proprotein convertase subtilisin/kexin type 9, antitocilizumab antibody and proteins responsible for degrading LDL receptor (2). Despite the beneficial effects of curcumin on components of metabolic syndrome such as hypertriglyceridemia, low high-density lipoprotein-cholesterol and central obesity(60, 61 ), it seems that this drug does not improve risk factors of CVD including cholesteryl ester transfer protein inhibitors (62) or $\mathrm{Lp}(\mathrm{a})$ (63) at doses prescribed in the studies.

Figure 2- Structural similarity between $\operatorname{Lp}(a)$ and LDL

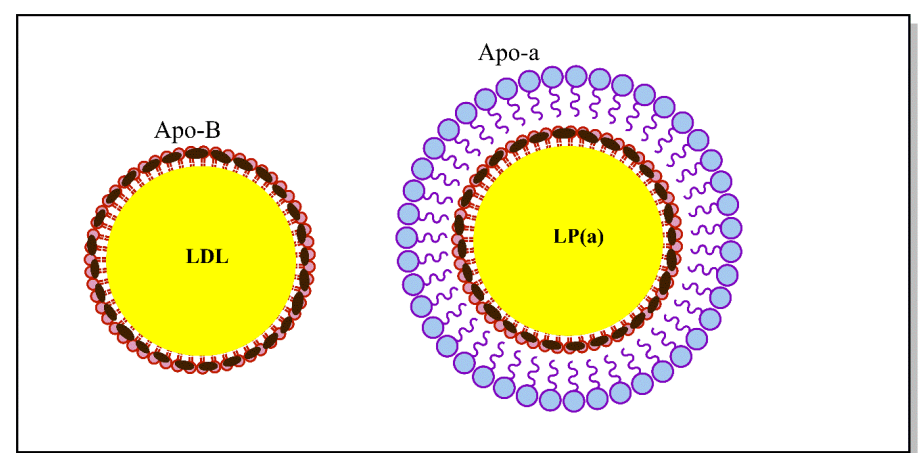

\section{CONCLUSION}

Increased level of $L p(a)$ is an independent risk factor for CVD events and has been observed in coronary artery disease and ischemic stroke events (64).

Lack of $L p(a)$ has no adverse effects on humans. However, the pathological effects of $\mathrm{Lp}(\mathrm{a})$ in vascular diseases with remaining oxidized LDL particles still requires further investigation.

Apolipoprotein(a) is highly glycated and can attach to several different extracellular matrices, thus participating in vascular diseases. However, $\mathrm{Lp}$ (a) also plays a role in tissue repair and may have a protective effect on LDL cholesterol. Lipoprotein(a) can be effective in wound healing, but it is not clear whether this effect is related to the affinity of apo(a) to the extracellular matrix composition. Apolipoprotein(a) degradation products have anti-tumor, anti-angiogenetic effects. In this case, the $L p(a) / a p o(a)$ can be beneficial for humans and therefore a relationship between $\mathrm{Lp}(\mathrm{a})$ and longer life expectancy can be anticipated. The balance between these roles of $L p(a) / a p o(a)$ can be a subject of future investigations (65). 


\section{REFERENCES}

1. McCormick SP. Lipoprotein(a): Biology and Clinical Importance. ClinBiochem Rev. 2004; 25(1): 69-80.

2. Maranhão RC, Carvalho PO, Strunz CC, PileggiF.Lipoprotein (a): structure, pathophysiology and clinical implications. Arq Bras Cardiol. 2014; 103(1): 7684.DOI:10.5935/abc.20140101

3. Berg K. A new serum type system in man--the LP system.ActaPatholMicrobiol Scand. 1963; 59: 36982.DOI:10.1111/j.1699-0463.1963.tb01808.x

4. Gaubatz JW, Chari MV, Nava ML, Guyton JR, Morrisett JD. Isolation and characterization of the two major apoproteins in human lipoprotein [a]. J Lipid Res. 1987; 28(1): 69-79.PMID: 2951469.

5. McLean JW, Tomlinson JE, Kuang WJ, Eaton DL, Chen EY, Fless GM, et al. cDNA sequence of human apolipoprotein (a) is homologous to plasminogen. Nature. 1987; 330(6144):132-7. DOI: 10.1038/330132a0.

6.Utermann G. The mysteries of lipoprotein(a). Science. 1989; 246(4932): 904-10.DOI: 10.1126/science. 2530631.

7. Scanu AM, Kurschinski D, Conn M, Garcia M. Important limiting features of the precipitation method in estimating LDL cholesterol: interference by IDL and Lp(a). Atherosclerosis.1988; 8: 574a.

8. Albers JJ, Adolphson JL, Hazzard WR. Radioimmunoassay of human plasma Lp(a) lipoprotein. $\mathrm{J}$ Lipid Res. 1977; 18(3): 331-8.PMID: 405443.

9. Jenner JL, Ordovas JM, Lamon-Fava S, Schaefer MM, Wilson PW, Castelli WP, et al. Effects of age, sex, and menopausal status on plasma lipoprotein(a) levels. The Framingham Offspring Study. Circulation. 1993; 87(4): 1135-41.DOI:10.1161/01.cir.87.4.1135.

10. White AL, Lanford RE. Cell surface assembly of lipoproteine(a) in primary cultures of baboon hepatocytes. J Biol Chem. 1994; 269(46): 2871623PMID: 7961823.

11. Krempler F, Kostner G, Bolzano K, Sandhofer F. Lipoprotein (a) is not a metabolic product of other lipoproteins containing apolipoproteinB.BiochimBiophysActa. 1979; 575(1): 6370. DOI:10.1016/0005-2760(79)90131-0.

12. Bartens W, Rader DJ, Talley G, Brewer HB Jr. Decreased plasma levels of lipoprotein $(a)$ in patients with hypertriglyceridemia. Atherosclerosis. 1994; 108(2): 149-57. DOI:10.1016/0021-9150(94)90109-0.

13. Santos RD, Vinagre C, Maranhão RC. Lipoprotein lipase does not affect lipoprotein (a) levels in normotriglyceridemic patients. Int J Cardiol. 1995; 50(1): 79-81.DOI:10.1016/0167-5273(95)02345-w.

14. Armstrong VW, Harrach B, Robenek H, Helmhold M, Walli AK, Slidel D. Heterogeneity of human lipoprotein Lp[a]: cytochemical and biochemical studies on the interaction of two Lp[a] species with the $L D L$ receptor. J Lipid Res. 1990; 31(3): 429-41.

15. Argraves KM, Kozarsky KF, Fallon JT, Harpel PC, Strickland DK. The atherogenic lipoprotein $\operatorname{Lp}(a)$ is internalized and degraded in a process mediated by the VLDL receptor. J Clin Invest. 1997; 100(9): 2170-81. DOI: 10.1172/JCI119753.

16. Wiklund O, Angelin B, Olofsson SO, Eriksson M, Fager G, Berglund L, et al. Apolipoprotein(a) and ischaemic heart disease in familial hypercholesterolaemia. Lancet. 1990; 335(8702): 13603.DOI:10.1016/0140-6736(90)91242-3.
17. Crawford DC, Peng Z, Cheng JF, Boffelli D, Ahearn $\mathrm{M}$, Nguyen $\mathrm{D}$, et al. $L P A$ and $P L G$ sequence variation and kringle IV-2 copy number in two populations. Hum Hered. 2008; 66(4): 199-209. DOI: 10.1159/000143403.

18. Boerwinkle E, Leffert CC, Lin J, Lackner C, Chiesa $\mathrm{G}$, Hobbs HH. Apolipoprotein(a) gene accounts for greater than $90 \%$ of the variation in plasma lipoprotein(a) concentrations. J Clin Invest. 1992; 90(1): 52-60. DOI: 10.1172/JCI115855.

19. Sandholzer C, Hallman DM, Saha N, Sigurdsson G, Lackner $\mathrm{C}$, Csaszar $\mathrm{A}$, et al. Effects of the apolipoprotein(a) size polymorphism on the lipoprotein(a) concentration in 7 ethnic groups. Hum Genet. 1991; 86(6): 607-14.DOI:10.1007/bf00201550.

20. Islam S, Gutin B, Smith C, Treiber F, Kamboh MI. Association of apolipoprotein(a) phenotypes in children with family history of premature coronary artery disease. ArteriosclerThromb. 1994; 14(10): 1609-16.

21. Moliterno DJ, Jokinen EV, Miserez AR, Lange RA, Willard JE, Boerwinkle E, et al. No association between plasma lipoprotein (a) concentrations and the presence or absence of coronary atherosclerosis in Afican American.ArteriosclerThrombVascBiol 1995; 15(7): 850-5.DOI:10.1161/01.atv.15.7.850.

22. Maeda S, Abe A, Seishima M, Makino K, Noma A, Kawade M. Transient changes of serum lipoprotein (a) as an acute phase protein. Atherosclerosis. 1989; 78(2-3): 145-50.DOI:10.1016/0021-9150(89)90218-9.

23. Ornek E, Murat S, Duran M, Turfan M, Kurtul A, Demircelik $\mathrm{MB}$, et al. The relationship between lipoprotein(a) and coronary artery disease, as well as its variable nature following myocardial infarction. Clin Invest Med. 2011; 34(1): E14-20. DOI:10.25011/cim.v34i1.14908.

24. Wang J, Hu B, Kong L, Cai H, Zhang C. Native, oxidized lipoprotein(a) and lipoprotein(a) immune complex in patients with active and inactive rheumatoid arthritis: plasma concentrations and relationship to inflammation.ClinChimActa. 2008; 390(1-2): 67-71. DOI: 10.1016/j.cca.2007.12.015.

25. Borba EF, Santos RD, Bonfa E, Vinagre CG, Pileggi FJ, Cossermelli W, et al. Lipoprotein (a) levels in systemic lupus erythematosus. J Rheumatol. 1994; 21(2): 220-3.

26. Enkhmaa B, Anuurad E, Zhang W, Abbuthalha A, Li $\mathrm{XD}$, Dotterweich $\mathrm{W}$, et al. HIV disease activity as a modulator of lipoprotein(a) and allele-specific apolipoprotein (a) levels. ArteriosclerThrombVasc Biol. 2013; $33(2): \quad 387-92 . \quad$ DOI: 10.1161/ATVBAHA.112.300125.

27. Maranhão R, Santos RD, Furlaneto $C$, Graziosi $P$, Stolf N, Vinagre C, et al. Lipoprotein (a), apolipoproteins and the lipid profile late after heart transplantation. Arq Bras Cardiol. 1994;63(6):465-8.

28. De Lima JJ, Maranhão RC, Latrilha M da C, Diament J, Romão JE, Krieger EM, et al. Early elevation of lipoprotein(a) levels in chronic renal insufficiency. Ren Fail. 1997; 19(1): 145-54.

29. Santos RD, Foronda A, Ramires JA, Maranhão RC. Levels of lipoprotein (a) in pulmonary arterial hypertension.Cardiol Young. 2001; 11(1): 259.DOI:10.1017/s1047951100012385. 
30. Bruckert E, Davidoff P, Grimaldi A, Truffert J, Giral $\mathrm{P}$, Doumith $\mathrm{R}$, et al. Increased serum levels of lipoprotein(a) in diabetes mellitus and their reduction with glycemic control. JAMA. 1990; 263(1): 356.doi:10.1001/jama.1990.03440010033016.

31. Haffner SM, Morales PA, Stern MP, Gruber MK. Lp(a) concentrations in NIDDM. Diabetes. 1992; 41(10): 1267-72.PMID: 1397699

32. Riches K, Porter KE. Lipoprotein(a): cellular effects and molecular mechanisms. Cholesterol. 2012; 2012: 923289.http://dx.doi.org/10.1155/2012/923289

33. Ramharack R, Barkalow D, Spahr MA. Dominant negative effect of TGF-betal and TNF-alpha on basal and IL-6-induced lipoprotein(a) and apolipoprotein(a) mRNA expression in primary monkey hepatocyte cultures. ArteriosclerThrombVasc Biol. 1998; 18(6): 98490.DOI:10.1161/01.atv.18.6.984.

34. Kostner GM, Avogaro P, Cazzolato G, Marth E, Bittolo-Bon G, Qunici GB. Lipoprotein Lp (a) and the risk for myocardial infarction. Atherosclerosis. 1981; 38(1-2): 51-61. DOI:10.1016/0021-9150(81)90103-9.

35. Murai A, Miyahara T, Fujimoto N, Matsuda M, Kameyama M. Lp(a) lipoprotein as a risk factor for coronary heart disease and cerebral infarction. Atherosclerosis. $\quad 1986$; $59(2)$ : $199-$ 204.DOI:10.1016/0021-9150(86)90048-1.

36. Rhoads GG, Dahlen G, Berg K, Morton NE, Dannenberg AL. Lp(a) lipoprotein as a risk factor for myocardial infarction. JAMA. 1986; 256(18): 25404.PMID: 2945939.

37. Maranhäo R, Arie S, Vinagre CG, Guimarães JB, Strunz C, Pileggi F. Lipoprotein (a) plasma levels in normal subjects and patients with coronary disease confirmed by coronary cineangiography. Arq Bras Cardiol. 1991; 56(2): 121-5.PMID: 1831344.

38. Frohlich J, Dobiásová M, Adler L, Francis M. Gender differences in plasma levels of lipoprotein $(a)$ in patients with angiographically proven coronary artery disease.Physiol Res. 2004; 53(5): 481-6.PMID: 15479125.

39. Virani SS, Brautbar A, Davis BC, Nambi V, Hoogeveen RC, Sharrett AR, et al. Associations between lipoprotein(a) levels and cardiovascular outcomes in black and white subjects: the Atherosclerosis Risk in Communities (ARIC) Study. Circulation. 2012; 125(2): 241-9. DOI: 10.1161/CIRCULATIONAHA.111.045120.

40. Sposito AC, Mansur AP, Maranhão RC, Martinez TR, Aldrighi JM, Ramires JA. Triglyceride and lipoprotein (a) are markers of coronary artery disease severity among postmenopausal women. Maturitas. 2001; 39(3): 203-8. DOI:10.1016/s0378-5122(01)00223-7.

41. Ridker PM, Hennekens CH, Stampfer MJ. A prospective study of lipoprotein(a) and the risk of myocardial infarction. JAMA.1993; 270: 2195-9.PMID: 8411602.

42. Wild SH, Fortmann SP, Marcovina SM. A prospective case-control study of lipoprotein(a) level and apo(a) size and risk of coronary heart disease in Stanford Five $\quad$ - City project. ArteriosclerThrombVascBiol. 1997; 17(2): 23945.DOI:10.1161/01.atv.17.2.239.
43. Baños-González MA, Peña-Duque MA, Anglés-Cano E, Martinez-Rios MA, Bahena A, Valente-Acosta B, et al. Apo(a) phenotyping and long-term prognosis for coronary artery disease.ClinBiochem. 2010; 43(7-8): 640-4. doi: 10.1016/j.clinbiochem.2010.01.013.

44. Salonen EM, Jauhiainen M, Zardi L, Vaheri A, Ehnholm C. Lipoprotein (a) binds to fibronectin and has serine protease activity capable of cleaving it. EMBO J. 1989; 8(13): 4035-40.

45. Bihari-Varga M, Graber E, Rotheneder M, Zechner $\mathrm{R}$, Kostner GM. Interaction of lipoproteinLp(a) and low density lipoprotein with glycosaminoglycans from human aorta.Arterosclerosis. $\quad 1988 ; \quad 8$ 851-7.doi: 10.1161/01.ATV.8.6.851.

46. Harpel PC, Gordon BR, Parker TS. Plasmin catalyzes binding of lipoprotein(a) to immobilized fibrinogen and fibrin.ProcNatlAcadSci USA.1989; 86: 3847-51. DOI:10.1073/pnas.86.10.3847.

47. Malle E, Ibovnik A, Steinmetz A, Kostner GM, Sattler W. Identification of glycoprotein IIb as the lipoprotein $(a)$ - binding protein on platelets. Lipoprotein(a) binding is independent of an ArginylGlycyl-Aspartate tripeptide located in apolipoprotein(a). ArteriosclerThromb. 1994; 14(3): 34552.

48. Köchl S, Fresser F, Lobentanz E, Baier G, Utermann G. Novel interaction of apolipoprotein (a) with $\beta 2$ glycoprotein I mediated by the kringle IV domain. Blood. 1997; 90(4): 1482-9.PMID: 9269765.

49. Niemeier A, Willnow T, Dieplinger H, Jacobsen C, Meyer $\mathrm{N}$, Hilpert $\mathrm{J}$, et al. Identification of megalin/gp330 as a receptor for lipoprotein(a) in vitro. ArteriosclerThrombVascBiol. 1999; 19(3): 552-61.

50. Vuckovic BA, Djeric MJ, Ilic TA, Canak VB, KojicDamjanovSLj, Zarkov MG, et al. Fibrinolytic parameters, lipid status and lipoprotein(a) in ischemic stroke patients. SrpArhCelokLek. 2010; 138 (Suppl 1): 12-7.DOI:10.2298/sarh10s1012v.

51. Kokoglu E, Karaarslan I, Karaarslan HM, Baloglu H. Elevated serum Lp(a) levels in the early and advanced stages of breast cancer. Cancer BiochemBiophys. 1994; 14(2): 133-6.PMID: 7889493.

52. Yang HH, Chen XF, Hu W, Lv DQ, Ding WJ, Tang $\mathrm{LI}$, Jiang JJ, Ye MH. Lipoprotein(a) level and its association with tumor stage in male patients with primary lung cancer.ClinChem Lab Med. 2009; 47(4): 452-7. doi: 10.1515/CCLM.2009.094.

53. Jiang $\mathrm{J}$, Nisson-Ehle $\mathrm{P}, \mathrm{Xu} \mathrm{N}$. Influence of liver cancer on lipid and lipoprotein metabolism. Lipids Health Dis.2006; 5: 4. DOI: 10.1186/1476-511X-5-4.

54. Yu HK, Kim JS, Lee HJ, Ahn JH, Lee SK, Hong SW, Yoon Y. Suppression of colorectal cancer liver metastasis and extension of survival by expression of apo(a) kringles. Cancer Res. 2004; 64(19): 7092-8. DOI: 10.1158/0008-5472.CAN-04-0364.

55. Lippi G, Franchini M, Salvagno GL, Guidi GC. Lipoprotein [a] and cancer: Anti-neoplastic effect besides its cardiovascular potency. Cancer Treatment Rev. 2007; 33(5): 427-36 
56. Hajjar KA, Nachman RL. The role of lipoprotein(a) in atherogenesis and thrombosis. Annual Rev Med. 1996; 47: 423-42. DOI: 10.1146/annurev.med.47.1.423.

57. Yano Y, Seishima M, Tokoro Y, Noma A. Stimulatory effects of lipoprotein(a) and low-density lipoprotein on human umbilical vein endothelial cell migration and proliferation are partially mediated by fibroblast growth factor-2. BiochimBiophysActa. 1998; 1393: 26-34.DOI:10.1016/s0005-2760(98)00052-6.

58. Mario Uccello, Giulia Malaguarnera, Elisa M. Pelligra, Antonio Biondi, Francesco Basile, andMassimo Motta. Lipoprotein(a) as a potential marker of residual liver function in hepatocellular carcinoma. Indian J Med PaediatrOncol. 2011; 32(2): 71-75.doi: 10.4103/09715851.89775.

59. Kostner K. Lipoprotein (a): Pathophysiology, metabolism, treatment options. Recent Advances and Research Updates. 2006;7(1):297-303.

60. Visioli F, Davalos A. Polyphenols and cardiovascular disease: a critical summary of the evidence. Mini Rev Med Chem. 2011;11(14):118690.DOI:10.2174/13895575111091186.

61. Moammeri SM, Parizadeh SMR, Pasdar A, Karimian MS, Safarian $\mathrm{H}$, Javandoost A, et al. The effect of curcumin (Curcuma longa L.) on circulating levels of adiponectin in patients with metabolic syndrome. Comparative Clinical Pathology. 2017;26(1):17-23.
62. Javandoost A, Afshari A, Saberi-Karimian M, Sahebkar A, Safarian H, Moammeri SM, et al. The effects of curcumin and a modified curcumin formulation on serum Cholesteryl Ester Transfer Protein concentrations in patients with metabolic syndrome: A randomized, placebo-controlled clinical trial. Avicenna journal of phytomedicine. 2018;8(4):330.DOI: 10.22038/ajp.2018.10348.

63. Saberi-Karimian M, Parizadeh SMR, GhayourMobarhan M, Moammeri SM, Dizaji BF, Safarian H, et al. Evaluation of the effects of curcumin in patients with metabolic syndrome. Comparative Clinical Pathology. 2018;27(3):555-63.

64. Forbes AC, Quek RGW, Deshpande S, Worthy G, Wolff $\mathrm{R}$, Stirk L, et al.The relationship between $\operatorname{Lp}(a)$ and CVD outcomes: a systematic review. Lipids in Health and Disease. 2016; 15:95. DOI: 10.1186/s12944016-0258-8.

65. Hsieh J. Lipoprotein(a) in Vascular Disease, Cancer and Longevity. Chang Gung medical journal. 2011; 34(6): $555-64$ 